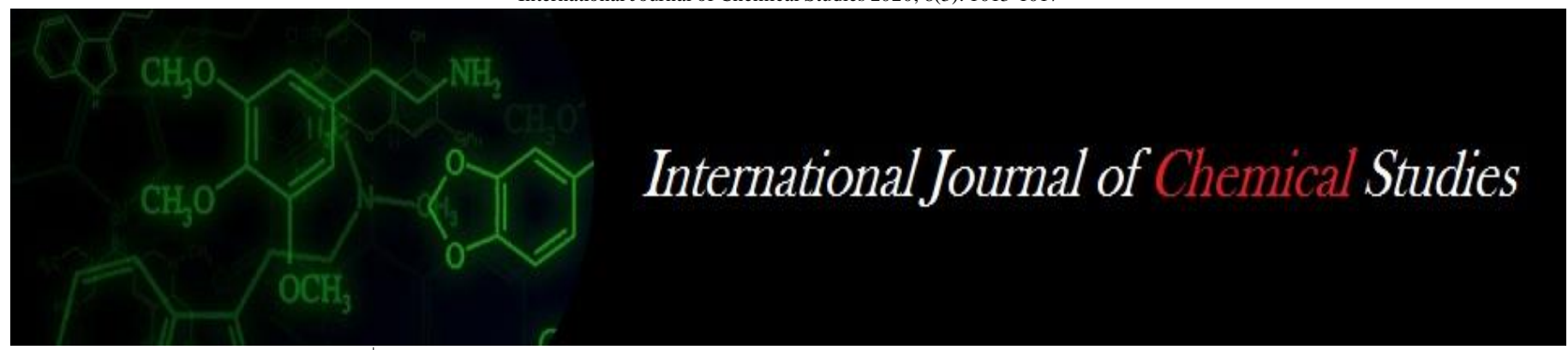

P-ISSN: 2349-8528

E-ISSN: 2321-4902

www.chemijournal.com

IJCS 2020; 8(3): 1013-1017

(C) 2020 IJCS

Received: 10-03-2020

Accepted: 12-04-2020

\section{SS Hadole}

Department of Soil Science and Agricultural Chemistry Dr.

Panjabrao Deshmukh Krishi

Vidyapeeth, Akola,

Maharashtra, India

\section{Gopal Patidar}

Dept. of SSAC, Dr. PDKV,

Akola, Maharashtra, India

\section{AB Age}

Dept. of SSAC, Dr. PDKV,

Akola, Maharashtra, India

\section{PA Sarap}

Dept. of SSAC, Dr. PDKV,

Akola, Maharashtra, India

\section{E Satyanaryana}

Prof. Jayashankar Telangana

State Agricultural University,

Hyderabad, Telangana, India

DT Dhule

College of Agriculture, Dr. PDKV, Akola, Maharashtra, India
Corresponding Author:

\section{SS Hadole}

Department of Soil Science and

Agricultural Chemistry Dr.

Panjabrao Deshmukh Krishi

Vidyapeeth, Akola,

Maharashtra, India

\section{Effect of fertigation on soil fertility, yield and nutrient uptake by brinjal}

\author{
SS Hadole, Gopal Patidar, AB Age, PA Sarap, E Satyanaryana and DT \\ Dhule
}

DOI: https://doi.org/10.22271/chemi.2020.v8.i3m.9329

\begin{abstract}
A field experiment was conducted to study the effect of fertigation on yield, soil fertility status and nutrient uptake by brinjal during rabi season of 2017-18 at research farm of Department of Irrigation and Drainage Engineering, Dr. Panjabrao Deshmukh Krishi Vidyapeeth, Akola, Maharashtra. The experiment was laid out in randomized block design with five treatments replicated four times. The treatments consist of various levels of fertilizers through drip fertigation and a control treatment with traditional application of fertilizer. The results revealed that the yield increased with increasing level of Fertigation. The maximum yield was recorded with drip fertigation at $150 \% \mathrm{RDF}\left(557.10 \mathrm{q} \mathrm{ha}^{-1}\right)$ which was found to be at par with drip Fertigation at $125 \%$ RDF $\left(554.88 \mathrm{q} \mathrm{ha}^{-1}\right)$. Significantly lower yield obtained under control i.e. traditional fertilization at $100 \% \operatorname{RDF}\left(428.56 \mathrm{q} \mathrm{ha}^{-1}\right)$. Similar trend was observed with highest available nitrogen, phosphorus, potassium and micronutrients in soil. Chemical properties of soil were also improved with fertigation as compared to traditional method of fertilizer application. Highest B:C ratio was obtained in treatment with drip fertigation at $125 \%$ RDF (3.22) followed by treatment with drip fertigation at $100 \%$ RDF (3.09).
\end{abstract}

Keywords: Fertigation, yield, nutrient uptake, soil fertility

\section{Introduction}

Brinjal is a staple vegetable in our diet. It is perfered both by poor and rich people. It is quite high in nutritive value and can be compared with tomato. It contains $92.7 \%$ water, $1.4 \%$ protein, $4.0 \%$ carbohydrates, $0.3 \%$ fats, $0.3 \%$ minerals, $1.3 \%$ fibre (Aykroyd, 1963) ${ }^{[1]}$.

Drip irrigation system increases yield by $10-12 \%$, reduces weed population by $50-60 \%$ and saves $40-50 \%$ water compared with surface irrigation system. In addition to this, it enhances fertilizer use efficiency, hastens crop maturity and improves the quality of the produce (Pawar et al. 2013) ${ }^{[11]}$. Fertigation, a technology of applying water soluble fertilizer through drip irrigation is one of important functionality of drip system. Fertigation has number of advantages over traditional methods like high nutrient use efficiency, increased yield and quality, placement of fertilizer in the vicinity of root zone of the crop, saving of fertilizer and application of trace element along with major nutrients (Pawar et al. 2013) ${ }^{[11]}$.

Mulching is used to cover soil surface around the plants to create congenial condition for the plant growth. Inorganic mulch includes plastic mulch and accounts for the greatest volume of mulch use in commercial crop production. The plastic materials used as mulch are polyvinyl chloride or polyethylene films. Polythene mulches are widely used in the cultivation of vegetables.

\section{Material and methods}

A field experiment was carried out during Rabi season of 2017-18 at research farm of Department of Irrigation and Drainage Engineering, Dr. P.D.K.V. Akola. The soil of the experimental site was low in available nitrogen (225.79 $\left.\mathrm{kg} \mathrm{ha}^{-1}\right)$, medium in available phosphorus (14.21 kg ha-1) and high in available potassium $\left(312.48 \mathrm{~kg} \mathrm{ha}^{-1}\right)$. The experiment was laid out in randomized block design with five treatments $\left(\mathrm{T}_{1}-75 \% \mathrm{RDF}, \mathrm{T}_{2}-100 \%\right.$ $\mathrm{RDF}, \mathrm{T}_{3}-125 \% \mathrm{RDF}, \mathrm{T}_{4}-150 \% \mathrm{RDF}$ all through drip fertigation and $\mathrm{T}_{5}-100 \% \mathrm{RDF}$ with traditional application of fertilizers) replicated four times. The recommended fertilizer dose of 150:75:75 N:P:K kg ha ${ }^{-1}$ was used. The seedlings were transplanted at $90 \mathrm{~cm} \mathrm{X} 75 \mathrm{~cm}$. The yield of brinjal was recorded in 20 pickings. Plot wise soil samples were collected and 
analyzed for $\mathrm{pH}$ (1:2.5 soil: water suspension), EC by conductivity meter (Jackson, 1973) ${ }^{[7]}$, organic carbon by Walkley and Black method (Nelson \& Sommers 1982) ${ }^{[10]}$, calcium carbonate by rapid titration method (Piper, 1966) ${ }^{[12]}$, available $\mathrm{N}$ by alkaline permanganate method (Subbiah and Asija, 1956) ${ }^{[16]}$, available P by Olsen's method (Watnabe and Olsen, 1965) ${ }^{[20]}$, available $\mathrm{K}$ by ammonium acetate extraction method (Jackson, 1973) ${ }^{[7]}$, available sulphur by simple turbidimetric method (Chesnin and Yein, 1951) [3] and available micronutrients $(\mathrm{Fe}, \mathrm{Mn}, \mathrm{Zn}, \mathrm{Cu})$ by extracting soil with 0.005 M DTPA (Lindsay and Norvell, 1978) ${ }^{[8]}$. The plant samples were collected at harvest and analysed for total nitrogen by Kjeldahl method from acid digestion (Piper, 1966) [12], total phosphorus by Vanado molybdate yellow colour method using diacid extract (Jackson, 1973) ${ }^{[7]}$, total potassium by Flame photometrically from diacid extract (Piper, 1966) ${ }^{[12]}$.

Total cost (fixed cost plus operating cost) per ha was calculated for comparison on per hectare basis. Gross return is worked out by considering the yield of produce and its selling price. Net return is calculated by subtracting cost of production from gross return in each treatment. Net return is calculated by subtracting cost of production from gross return in each treatment.

Benefit cost ratio was estimated by using following formula.
Gross return per season
Benefit cost ratio $=$
Total cost per season

\section{Results and discussion \\ Yield}

The data on yield of brinjal (Table 1) indicated that treatment $\mathrm{T}_{4}$ i.e. Drip fertigation at $150 \% \mathrm{RDF}$ recorded significantly highest yield (557.10 $\left.\mathrm{q} \mathrm{ha}^{-1}\right)$ and it was found at par with treatment $\mathrm{T}_{3}$ i.e. Drip fertigation at $125 \% \operatorname{RDF}\left(554.88 \mathrm{q} \mathrm{ha}^{-1}\right)$, followed by treatments of drip fertigation at $100 \% \mathrm{RDF}$ and drip fertigation at $75 \%$ RDF. Lowest yield (428.56 $\left.\mathrm{q} \mathrm{ha}^{-1}\right)$ was observed in treatment $\mathrm{T}_{5}$ (Traditional fertilization at $100 \%$ RDF). Yield obtained was higher in case of drip fertigation because of more availability of nutrients throughout growth period of crop, whereas, in traditional fertilization treatment, yield may be low due to application of whole dose of fertilizer during vegetative growth which may affected the availability of nutrients at flowering and fruiting stage of crop. The results are in conformity with the findings of Ughade and Mahadkar (2015) [19] and Xiukang et al. (2016) [21]. Ughade and Mahadkar (2015) ${ }^{[19]}$ conducted an experiment and found that between different levels of fertigation the higher fertigation level recorded significantly higher yield of brinjal. Xiukang et al. (2016) ${ }^{[21]}$ evaluated that tomato yield was significantly influenced by fertilizer rate which is higher for higher fertigation rate.

Table 1: Yield of brinjal as influenced by different levels and methods of fertilizer application

\begin{tabular}{|c|c|}
\hline Treatments & Yield (q ha-1) \\
\hline $\mathrm{T}_{1}$ (Drip fertigation at 75\% RDF) & 443.94 \\
\hline $\mathrm{T}_{2}$ (Drip fertigation at 100\% RDF) & 499.67 \\
\hline $\mathrm{T}_{3}$ (Drip fertigation at 125\% RDF) & 554.88 \\
\hline $\mathrm{T}_{4}$ (Drip fertigation at 150\% RDF) & 557.10 \\
\hline $\mathrm{T}_{5}$ (Traditional fertilization at 100\% RDF) & 428.56 \\
\hline SE (m) \pm & 17.78 \\
\hline CD at 5\% & 54.78 \\
\hline CV\% & 7.16 \\
\hline
\end{tabular}

\section{Chemical properties of soil}

Data regarding chemical properties of soil is presented in Table 2. $\mathrm{pH}$ and calcium carbonate content of soil were not significantly influenced by various levels and methods of fertilizer application. The electrical conductivity of soil as influenced by different treatments was statistically significant. The highest value of EC $\left(0.38 \mathrm{dS} \mathrm{m} \mathrm{m}^{-1}\right)$ was observed in control treatment $\mathrm{T}_{5}$ (Traditional fertilization at $100 \% \mathrm{RDF}$ ). The lowest EC $\left(0.30 \mathrm{dS} \mathrm{m}^{-1}\right)$ was recorded in the treatment $\mathrm{T}_{4}$ (Drip fertigation at $150 \% \mathrm{RDF}$ ) and it was found to be at par with treatment $\mathrm{T}_{3}$ (Drip fertigation at $125 \% \mathrm{RDF}$ ). The significantly highest $(0.64 \%)$ organic carbon was recorded in the treatment $\mathrm{T}_{4}$ (Drip fertigation at $150 \% \mathrm{RDF}$ ) and it was found to be at par with treatment $\mathrm{T}_{3}$ (Drip fertigation at $125 \%$ $\mathrm{RDF})$. The lowest $(0.49 \%)$ organic carbon was recorded in the treatment $\mathrm{T}_{5}$ (Traditional fertilization at $100 \% \mathrm{RDF}$ ). Organic carbon content in surface soil was increased significantly due to application of fertilizers as the application of increasing fertilizer rate helped in increasing the biomass production. Increased root biomass added to the organic carbon content of soil. Similar results were also reported by Tank and Patel (2013) ${ }^{[17]}$ and Singh et al. (2018) ${ }^{[14]}$. Tank and Patel (2013) [17] revealed that organic carbon content in surface soil was increased significantly due to application of fertilizers as the application of fertilizer helped in increasing the biomass production. Organic carbon was higher with higher fertigation rates i.e. $0.60 \%$ at $60 \% \mathrm{RDF}$ and $0.66 \%$ at $100 \% \mathrm{RDF}$ in papaya. Singh et al. (2018) ${ }^{[14]}$ found that increasing fertilizer doses tend to increase the organic carbon to the extent of 0.61 , 0.63 and $0.64 \%$ under $F_{1}, F_{2}$ and $F_{3}$, respectively in banana.

Table 2: Soil properties as influenced by different levels and methods of fertilizer application

\begin{tabular}{|c|c|c|c|c|}
\hline Treatments & $\mathbf{p H}(\mathbf{1 : 2 . 5})$ & $\left.\mathbf{E C ~} \mathbf{d S ~ m}^{-\mathbf{1}}\right)$ & $\mathbf{O C}(\mathbf{\%})$ & $\mathbf{C a C O} \mathbf{3}(\mathbf{\%})$ \\
\hline $\mathrm{T}_{1}$ (Drip fertigation at 75\% RDF) & 7.56 & 0.37 & 0.51 & 7.10 \\
\hline $\mathrm{T}_{2}$ (Drip fertigation at 100\% RDF) & 7.52 & 0.35 & 0.54 & 7.07 \\
\hline $\mathrm{T}_{3}$ (Drip fertigation at 125\% RDF) & 7.50 & 0.32 & 0.57 & 7.01 \\
\hline $\mathrm{T}_{4}$ (Drip fertigation at 150\% RDF) & 7.48 & 0.30 & 0.64 & 6.94 \\
\hline $\mathrm{T}_{5}$ (Traditional fertilization at 100\% RDF) & 7.57 & 0.38 & 0.49 & 7.19 \\
\hline SE (m) \pm & 0.02 & 0.01 & 0.03 & 0.06 \\
\hline CD at 5\% & $\mathrm{NS}$ & 0.04 & 0.09 & $\mathrm{NS}$ \\
\hline Initial status & 7.61 & 0.39 & 0.48 & 7.22 \\
\hline
\end{tabular}




\section{Soil fertility status \\ Major nutrients}

Table 3 shows the data regarding soil fertility status at harvest. The significantly highest available $\mathrm{N}\left(266.56 \mathrm{~kg} \mathrm{ha}^{-1}\right)$ in soil was recorded in the treatment $\mathrm{T}_{4}$ (Drip fertigation at $150 \% \mathrm{RDF}$ ) and it was found to be at par with treatment $\mathrm{T}_{3}$ (Drip fertigation at $125 \% \mathrm{RDF}$ ). The lowest available $\mathrm{N}$ $\left(228.93 \mathrm{~kg} \mathrm{ha}^{-1}\right.$ ) was recorded in the treatment $\mathrm{T}_{5}$ (Traditional fertilization at $100 \% \mathrm{RDF})$. Similar trend was observed in case of available potassium. Significantly highest available $\mathrm{P}$ (18.98 $\mathrm{kg} \mathrm{ha}^{-1}$ ) was recorded in the treatment $\mathrm{T}_{4}$ (Drip fertigation at $150 \% \mathrm{RDF}$ ) and it was found to be at par with treatment $\mathrm{T}_{3}$ (Drip fertigation at $125 \% \mathrm{RDF}$ ) and $\mathrm{T}_{2}$ (Drip fertigation at $100 \% \mathrm{RDF})$. The lowest available $\mathrm{P}(14.57 \mathrm{~kg}$ $\mathrm{ha}^{-1}$ ) was recorded in the treatment $\mathrm{T}_{5}$ (Traditional fertilization at $100 \% \mathrm{RDF}$ ). The split application of fertilizers through drip fertigation increased the availability of nitrogen, phosphorus and potassium in soil. The increased available $\mathrm{N}$,
$\mathrm{P}$ and $\mathrm{K}$ with higher level of fertilizer application might be due to direct contribution towards the available $\mathrm{N}, \mathrm{P}$ and $\mathrm{K}$ pool in soil. Similar results were observed by Shedeed et al. (2009) ${ }^{[13]}$, Tank and Patel (2013) ${ }^{[17]}$ and Brewer et al. (2018) ${ }^{[2]}$. Shedeed et al. (2009) ${ }^{[13]}$ conducted a field experiment and found that in drip fertigated tomato fertigation maintained higher concentration of $\mathrm{NO}_{3}{ }^{-}-\mathrm{N}, \mathrm{P}$ and $\mathrm{K}$ in soil being higher with increasing rate of fertigation. Tank and Patel (2013) ${ }^{[17]}$ also revealed that the plots treated with higher level of fertilizers recorded higher available $\mathrm{N}$ in soil which was 252 $\mathrm{kg} \mathrm{ha}^{-1}$ at $60 \% \mathrm{RDF}$ and $286 \mathrm{~kg} \mathrm{ha}^{-1}$ at $100 \% \mathrm{RDF}$ in papaya. Brewer et al. (2018) ${ }^{[2]}$ found that soil $\mathrm{NH}_{4}{ }^{+}$and $\mathrm{NO}_{3}{ }^{-}$ concentration increased with fertilizer $\mathrm{N}$ rate which is significantly greater with greater fertilizer $\mathrm{N}$ rate in drip irrigated tomato. Available sulphur was non significantly influenced by various levels and methods of fertilizer application.

Table 3: Available nutrient status in soil as influenced by different levels and methods of fertilizer application

\begin{tabular}{|c|c|c|c|c|c|}
\hline \multicolumn{2}{|c|}{ Treatment } & \multicolumn{4}{c|}{ Available nutrients } \\
\cline { 3 - 6 } \multicolumn{2}{|c|}{} & $\mathbf{N}\left(\mathbf{k g ~ h a}^{-1}\right)$ & $\mathbf{P}\left(\mathbf{k g ~ h a}^{-\mathbf{1}}\right)$ & $\mathbf{K}\left(\mathbf{k g ~ h a}^{-\mathbf{1}}\right)$ & $\mathbf{S}\left(\mathbf{m g ~ k g}^{\mathbf{- 1}}\right)$ \\
\hline $\mathrm{T}_{1}$ & Drip fertigation at 75\% RDF & 232.06 & 15.46 & 324.80 & 7.32 \\
\hline $\mathrm{T}_{2}$ & Drip fertigation at 100\% RDF & 235.20 & 16.30 & 333.20 & 8.01 \\
\hline $\mathrm{T}_{3}$ & Drip fertigation at 125\% RDF & 254.01 & 18.06 & 355.60 & 8.58 \\
\hline $\mathrm{T}_{4}$ & Drip fertigation at 150\% RDF & 266.56 & 18.98 & 369.60 & 8.80 \\
\hline $\mathrm{T}_{5}$ & Traditional fertilization at 100\% RDF & 228.93 & 14.57 & 319.20 & 7.21 \\
\hline & SE (m) \pm & 8.8 & 0.98 & 9.82 & 0.45 \\
\hline & CD at 5\% & 27.1 & 3.03 & 30.26 & $\mathrm{NS}$ \\
\hline & Initial status & 225.79 & 14.21 & 312.48 & 7.15 \\
\hline
\end{tabular}

\section{Micronutrients}

The data regarding micronutrients availability in soil at harvest of brinjal is presented in Table 4. The highest iron and zinc content in soil was observed in the treatment $\mathrm{T}_{4}$ (Drip fertigation at $150 \% \mathrm{RDF}$ ) and it was found to be at par with treatment $\mathrm{T}_{3}$ (Drip fertigation at $125 \% \mathrm{RDF}$ ). The lowest available iron and zinc was recorded in the treatment $\mathrm{T}_{5}$ (Traditional fertilization at $100 \%$ RDF). The significantly highest available copper was observed with the treatment $\mathrm{T}_{4}$ (Drip fertigation at $150 \% \mathrm{RDF}$ ), while, the lowest available copper was recorded in the treatment $\mathrm{T}_{5}$ (Traditional fertilization at $100 \% \mathrm{RDF})$. The results are in conformity with the findings of Glonek and Komosa (2013) ${ }^{[6]}$ and Elhindi et al. (2016) ${ }^{[5]}$. Glonek and Komosa (2013) ${ }^{[6]}$ revealed that in highbush blueberry fertigation of nutrient solutions in relation to drip irrigation, resulted in the increasing contents of micronutrients in soil. The effect of fertigation and traditional application of fertilizer on available manganese was found to be non-significant.

Table 4: Available micronutrients in soil as influenced by different levels and methods of fertilizer application

\begin{tabular}{|c|c|c|c|c|c|}
\hline \multicolumn{2}{|c|}{ Treatment } & \multicolumn{3}{c|}{ Available micronutrients $\left(\mathbf{m g ~ k g}^{-1}\right)$} \\
\cline { 3 - 6 } \multicolumn{2}{|c|}{} & $\mathbf{F e}$ & $\mathbf{M n}$ & $\mathbf{C u}$ & $\mathbf{Z n}$ \\
\hline $\mathrm{T}_{1}$ & Drip fertigation at 75\% RDF & 5.38 & 11.20 & 3.36 & 0.59 \\
\hline $\mathrm{T}_{2}$ & Drip fertigation at 100\% RDF & 5.45 & 11.25 & 3.56 & 0.62 \\
\hline $\mathrm{T}_{3}$ & Drip fertigation at 125\% RDF & 6.06 & 11.32 & 3.64 & 0.65 \\
\hline $\mathrm{T}_{4}$ & Drip fertigation at 150\% RDF & 6.43 & 11.42 & 3.98 & 0.68 \\
\hline $\mathrm{T}_{5}$ & Traditional fertilization at 100\% RDF & 5.33 & 11.09 & 3.23 & 0.57 \\
\hline & SE (m) \pm & 0.186 & 3.56 & 0.106 & 0.019 \\
\hline & CD at 5\% & 0.572 & $\mathrm{NS}$ & 0.326 & 0.059 \\
\hline & Initial status & 5.24 & 11.03 & 3.16 & 0.55 \\
\hline
\end{tabular}

\section{Total nutrient uptake}

The data presented in Table 5 revealed that the total uptake of nitrogen by brinjal plant at harvest was significantly influenced due to different fertigation levels and traditional method of fertilizer application. Significantly higher nitrogen uptake $\left(130.68 \mathrm{~kg} \mathrm{ha}^{-1}\right)$ was observed in treatment $\mathrm{T}_{4}$ (Drip fertigation at $150 \% \mathrm{RDF}$ ) and it was found to be at par with treatment $\mathrm{T}_{3}$ i.e. Drip fertigation at $125 \% \mathrm{RDF}\left(120.68 \mathrm{~kg} \mathrm{ha}^{-}\right.$ $\left.{ }^{1}\right)$. While the lowest nitrogen uptake $\left(70.37 \mathrm{~kg} \mathrm{ha}^{-1}\right)$ was recorded in the treatment $\mathrm{T}_{5}$ (Traditional fertilization at $100 \%$ $\mathrm{RDF})$. Similar trend was observed with total $\mathrm{P}$ and $\mathrm{K}$ uptake by brinjal. Increased nutrient uptake by plant was due to the higher availability of nutrient in the root zone. Similar findings were reported by Christou et al. (1999) [4], Mohammad et al. (2004) ${ }^{[9]}$, Ugade et al. (2014) ${ }^{[18]}$ and Sollapur and Hiremath (2017) ${ }^{[15]}$. Ugade et al. (2014) ${ }^{[18]}$ conducted a field experiment and found that the uptake of nitrogen was increased with increasing fertigation levels of $\mathrm{N}$, $\mathrm{P}$ and $\mathrm{K}$ in brinjal. Sollapur and Hiremath $(2017)^{[15]}$ revealed that application of higher fertilizer levels increases nutrient uptake in hybrid brinjal. 
Table 5: Total nutrient uptake by brinjal as influenced by different levels and methods of fertilizer application

\begin{tabular}{|c|c|c|c|c|}
\hline \multicolumn{2}{|c|}{ Treatment } & \multicolumn{3}{|c|}{ Nutrient Uptake (Kg ha-1) } \\
\cline { 2 - 5 } & P Uptake & K Uptake \\
\hline $\mathrm{T}_{1}$ & Drip fertigation at 75\% RDF & 78.16 & 20.17 & 85.32 \\
\hline $\mathrm{T}_{2}$ & Drip fertigation at 100\% RDF & 93.83 & 26.91 & 105.93 \\
\hline $\mathrm{T}_{3}$ & Drip fertigation at 125\% RDF & 120.68 & 36.72 & 134.53 \\
\hline $\mathrm{T}_{4}$ & Drip fertigation at 150\% RDF & 130.68 & 40.86 & 144.38 \\
\hline $\mathrm{T}_{5}$ & Traditional fertilization at 100\% RDF & 70.37 & 17.58 & 73.72 \\
\hline & SE (m) \pm & 5.86 & 1.49 & 4.99 \\
\hline & CD at 5\% & 18.06 & 4.59 & 15.38 \\
\hline & CV\% & 11.87 & 10.47 & 9.18 \\
\hline
\end{tabular}

\section{Cost economics of the study}

Cost economics of the study shows that the highest net monetary returns was obtained in treatment $\mathrm{T}_{3}$ i.e. fertigation with $125 \%$ RDF (267653 Rs ha-1) followed by treatment $\mathrm{T}_{4}$ i.e. fertigation with $150 \%$ RDF (261580 Rs ha ${ }^{-1}$ ). Highest B:C ratio was obtained in treatment $\mathrm{T}_{3}$ i.e. fertigation with $125 \%$ RDF (3.22) followed by treatments $\mathrm{T}_{2}$ i.e. fertigation with $100 \%$ RDF (3.09) as depicted in Table 6.

Table 6: Cost economics of the study

\begin{tabular}{|c|c|c|c|c|c|}
\hline Treatment & $\begin{array}{c}\text { Yield of brinjal } \\
\left(\mathbf{q} \mathbf{~ h a}^{-1}\right)\end{array}$ & Gross return $\left(\mathbf{R s ~ h a}^{-\mathbf{1}}\right)$ & $\begin{array}{c}\text { Total cost } \\
\left(\mathbf{R s ~ h a}^{-1}\right)\end{array}$ & Net return $\left(\mathbf{R s ~ h a}^{-\mathbf{1}}\right)$ & $\mathbf{B : C ~}^{\text {ratio }}$ \\
\hline $\mathrm{T}_{1}$ (Drip fertigation at 75\% RDF) & 443.94 & 310758 & 105502 & 205256 & 2.95 \\
\hline $\mathrm{T}_{2}$ (Drip fertigation at 100\% RDF) & 499.67 & 349771 & 113131 & 236640 & 3.09 \\
\hline $\mathrm{T}_{3}$ (Drip fertigation at 125\% RDF) & 554.88 & 388414 & 120761 & 267653 & 3.22 \\
\hline $\mathrm{T}_{4}$ (Drip fertigation at 150\% RDF) & 557.10 & 389971 & 128391 & 261580 & 3.04 \\
\hline $\mathrm{T}_{5}$ (Traditional fertilization at 100\% RDF) & 428.56 & 299991 & 98733 & 201258 & 3.04 \\
\hline
\end{tabular}

\section{Conclusion}

The initial soil analysis indicated that soil was low in available nitrogen and medium in available phosphorus so increased level of drip fertigation give quick response. Higher yield of brinjal with improvement in nutrient uptake and chemical properties of soil was obtained in treatment $\mathrm{T}_{4}$ (drip fertigation at $150 \% \mathrm{RDF}$ ) and was found at par with $\mathrm{T}_{3}$ (drip fertigation at $125 \% \mathrm{RDF}$ ). Also, B:C (Benefit: Cost) ratio was higher in treatment $\mathrm{T}_{3}$ (drip fertigation at $125 \% \mathrm{RDF}$ ). On the basis of benefit cost ratio and net monetary returns, it is economically viable for the farmers to adopt drip fertigation at $125 \%$ RDF Hence, drip fertigation at $125 \% \mathrm{RDF}\left(\mathrm{T}_{3}\right)$ along with silver polyethylene mulch was found superior to obtain higher yield of brinjal and highest benefit cost ratio.

\section{References}

1. Aykroyd WR. Composition of brinjal fruit. ICMR special Rept, 1963, 42.

2. Brewer MT, Morgan KT, Zotarelli L, Stanley CD, Kadyampaken D. Effect of drip irrigation and nitrogen, phosphorus and potassium application rates on tomato biomass accumulation, nutrient content, yield, and soil nutrient status. J Hortic. 2018; 5:227.

3. Chesnin L, Yien CH. Turbidimetric determination of available sulphates. Soil Sci. Soc. Am. 1951; 15:149-151.

4. Christou M, Dumas Y, Dimirkou A, Vassiliou Z. Nutrient uptake by processing tomato in greece. Part 1 Proct. $6^{\text {th }}$ Int ISHS Symp on the Processing Tomato, Acta hort. 1999; 487:221-223.

5. Elhindi K, El-Hendawy S, Salam EA, Elgorban A. Impacts of fertigation via surface and subsurface drip irrigation on growth rate, yield and flower quality of Zinnia elegans. Bragantia, Campinas. 2016; 75(1):96107.

6. Glonek J, Komosa A. fertigation of highbush blueberry (vaccinium corymbosum 1.). part II. the effect on soil nutrient content. Acta Sci. Pol., Hortorum Cultus. 2013; 12(3):59-68.
7. Jackson ML. Soil Chemical Analysis, Printice Hall of India Pvt. Ltd., New Delhi, 1973, 458p.

8. Lindsay WL, Norvell WA. Development of DTPA soil test zinc, iron, manganese and copper. Soil Sci. Soc. Am. J. 1978; 42:421-448.

9. Mohammad MJ, Hammouri A, Ferdows AE. Phosphorus fertigation and preplant conventional soil application of drip irrigated summer squash. Journal of Agronomy. 2004; 3(3): 162-169.

10. Nelson, Sommers LE. Total carbon, organic carbon and organic matter. In: methods of Soil Analysis Part- II. Page, A.L. (Ed.). Am. Soc. of Agron. Inc. Soil Sci. Soc. Am. Madison, Wisconsin, USA, 1982, 539-577.

11. Pawar DD, Dingre SK, Shinde MG, Kaore SV. Drip fertigation for higher crop productivity., MPKV Res, Pub. 2013; 99:3.

12. Piper CS. Soil and Plant analysis. Hans Publisher Bombay, 1966.

13. Shedeed SI, Zaghloul SM, Yassen AA. Effect of method and rate of fertilizer application under drip irrigation on yield and nutrient uptake by tomato. Ozean Journal of Applied Sciences. 2009; 2(2):139-147.

14. Singh TB, Patra SK, Chanu LJ, Singh LK. Influence of drip fertigation on physico-chemical properties of an alluvial soil of West Bengal, India. Int. J. Curr. Microbiol. App. Sci. 2018; 7(12):3535-3543.

15. Sollapur DL, Hiremath SM. Effects of planting geometry and fertilizer levels on growth and yield of hybrid brinjal. Internat. J. agric. Sci. 2017; 13(1):97-100.

16. Subbiah BV, Asija GL. A procedure for estimation of available nitrogen in soils. Current Science. 1956; 25:260.

17. Tank RV, Patel NL. Influence of fertigation on yield and nutrient status in soil and leaf of papaya (Carica papaya L.) var. Madhu Bindu under south Gujarat condition. The Asian Journal of Horticulture. 2013; 8(1):170-173.

18. Ugade SR, Ayare BL, Thorat TN, Thoka RT. Effect of irrigation and fertigation levels on yield and nutrient 
uptake of brinjal (Solanum melongena L.), International Journal of Agricultural Engineering. 2014; 7:74-80.

19. Ughade SR, Mahadkar UV. Effect of different planting density, irrigation and fertigation levels on growth and yield of brinjal (Solanum melongena L.). The Bioscan. 2015; 10(3):1205-1211.

20. Watanabe FS, Olsen SR. Test of ascorbic acid method for determining phosphorus in water and sodium bicarbonate extracts of soils. Soil Science Society of America Proceedings. 1965; 29:677-678.

21. Xiukang W, Yingying X. Evaluation of the effect of irrigation and fertilization by drip fertigation on tomato yield and water use efficiency in greenhouse. International Journal of Agronomy. 2016; 3961903:1-10. 